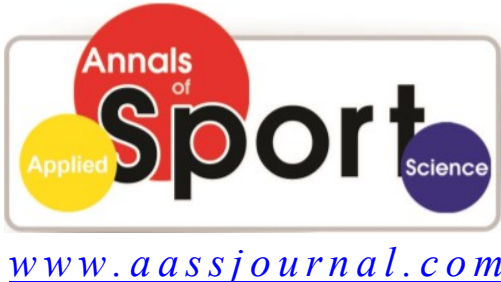

ISS N (Online): $2322-4479$

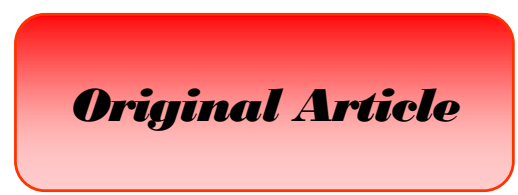

Received: 26/04/2014

Accepted: 27/07/2014

\title{
The Relationship of Organizational Culture and Entrepreneurship with Effectiveness in Sport Organizations
}

\section{${ }^{1}$ Masoumeh Kalateh Seifari*, ${ }^{2}$ Zahra Amoozadeh}

1. Department of Sport Management, Mazandaran University, Babolsar, Iran.

2. Department of Sport Management, Kharazmi University, Tehran, Iran.

\begin{abstract}
One of the most important factors affecting organizational effectiveness is organizational culture and entrepreneurship. The aim of the present study was to determine the relationship of organizational culture and corporate entrepreneurship with effectiveness in offices of sport and youth in Golestan Province. Research method was correlation and the statistical population included all directors and experts of general directorates of sport and youth in Golestan province $(\mathrm{N}=280) .164$ persons were randomly selected as the sample. The required data were collected by using Denison Organizational Culture Survey (DCOS), author-made Corporate Entrepreneurship Questionnaire, and Effectiveness Inventory (Heydari Nejad and Saberi, 2010). The results showed that there is a positive and significant relationship between organizational culture and effectiveness $(\mathrm{r}=0.457)$ and also between corporate entrepreneurship and effectiveness $(\mathrm{r}=0.795)$. The results also indicated that organizational culture and corporate entrepreneurship are good predictors of organizational effectiveness. Generally, in sport organizations, because of the nature of sport and physical activities, effectiveness would be ideal when teamwork culture, support for initiative and creativity, and flexible structure encourage employees to innovate.
\end{abstract}

Key Words: Organizational Culture, Corporate Entrepreneurship, Effectiveness.

Corresponding Author:

Masoumeh Kalateh Seifari

E-mail: ma.kalatehseifari@yahoo.com 


\section{INTRODUCTION}

Sustainable productivity, change, innovation, and quality of life are the most important general objectives that governments and organizations pursue. Sport can influence national productivity and thereby positively affect the economic prosperity. Optimal use of resources or "efficiency" and achieving the goals or "effectiveness" are essential to reach "productivity". A combination of efficiency and effectiveness forms productivity. So, the higher the efficiency and effectiveness are, the greater the productivity would be. Performance effectiveness index is used to evaluate the extent of goals acquisition (1).

The concept of effectiveness is one of the most important issues in understanding of organizational behavior (2). Researchers are constantly seeking for the most important factors affecting organizational effectiveness (3). Organizational culture and entrepreneurship are of the most important factors affecting organizational effectiveness. For example, sometimes applying change strategies in order to achieve development and organizational effectiveness is delayed or not accepted, because they are in contrast to the organization culture (a set of organizational beliefs). As a result, the organization moves towards decline, inefficiency, and ineffectiveness (4).

The scholars of management and organizational behavior define effectiveness as the extent to which an organization achieve its objectives (5). Due to the vast changes in today's world and intensified competitions, many researchers have focused on propose appropriate strategies for organizational effectiveness and rapid and effective implementation of them. In addition to achieving higher levels of excellence, organizational culture can improve the ability of sport organizations to implement new operational strategies (6). On the other hand, learning and innovation is an essential requirement for organizations that are seeking survival and effectiveness and many organizations are seeking innovative and entrepreneurial approaches and methods in order to improve their effectiveness, efficiency, and flexibility. Accordingly, corporate entrepreneurship is becoming a weapon for many organizations, especially large ones. Corporate entrepreneurship is an attempt to create entrepreneurial mentalities and skills and also to corporate them into the culture and activities of an organization (7).

In today's word, innovation and entrepreneurship and using them in organization is inevitable. If planners, decision-makers, and the staff of an organization are entrepreneur, they better understand economic opportunities are able to use the existing resources for more innovation, so that their organization grow faster and survive more in today's competitive market. In order to achieve this goal, entrepreneurial activities should be encouraged, entrepreneurial spirit should be fostered among the decision-makers and staff, and an entrepreneurial atmosphere should be provided in organizations (8).

Accordingly, the study of entrepreneurship is currently one of the most popular areas of research in management studies. Hence, it would not be an exaggeration to say that entrepreneurship has been an important issue raised in the community, education, and scientific research in recent decades (9). Guzmán Cuevas and Cáceres Carrasco (2007) emphasized on entrepreneurial structure as an important and essential factor for regional economic growth (10). Nayager and Van Vuuren (2005) believe that continuous innovation and entrepreneurship is the only way of organizations to achieve success in today's dynamic and competitive environment (11). Marlow (2006) defines entrepreneurship as a collective phenomenon and thereby a creative team activity (12). The 
results of study by Pertusa-Ortega, ZaragozaSáez, and Claver-Cortés (2010) showed that organizational complexity and focus, respectively, have a negative and positive relationship with entrepreneurship (13). Kuratko and Hodgetts (1992), Smerek and Denison (2007), Denison et al. (2006), Mirzaei Ahranjani and Moghimi (2003), and Seyedhoseini (2002) also reported a relationship between organizational culture and entrepreneurship (14-18). In terms of organizational culture and effectiveness, the results of studies by Faerman (2009), Kwantes and Boglarsky (2007), and Ghorbani, Asadi, and Sharifi (2010) showed that there is a significant relationship between organizational culture and organizational effectiveness $(4,19,20)$. In addition, Gregory et al. (2009) and Yilmaz and Ergun (2008) showed that organizational culture has a significant impact on organizational effectiveness $(21,22)$.

About the relationship between entrepreneurship and effectiveness, Seifisaldehi et al. (2012) and Karimpour, Imani, and Chehrzad (2012) showed that there is a significant relationship between these two variables $(23,24)$. Since sport organizations, as the custodians of sport, play the main role in achieving the goals such as the development, promotion, and growth of sport and as Peter Drucker states, organizational effectiveness means the extent to which an organization has achieved its objectives, it is necessary that organization act effectively to achieve the aforesaid goals and if so, they can successfully manage the sport system and approach more optimal effectiveness.

In the administrative divisions, after the Ministry of Sport and Youth, the general directorates in provincial capitals and offices in cities are the executive arms of sport in our country. Having 12 offices of sport and youth, Golestan Province has always been one of the most active provinces in the field of sports and athletics. The questions have always been in the mind of the author that whether sport organizations has the desired effectiveness or not, whether the objectives, strategies, policies, programs, and projects for improvement of sport have always been fruitful or not, from the perspective of the custodians of sport in our country, and whether the general objectives of sport have sometimes determined wrongly or not.

Only in organizations with cultural entrepreneurial features, managers of public and private organizations are able to reach maximum effectiveness and efficiency, otherwise the optimal organizational growth and development will not be achieved in the era of changes and upheavals. Given the dynamism of organizations in order to achieve the desired effectiveness, sport organizations are no exception. Recognizing the importance of the concept of effectiveness, the author aims to study organizational effectiveness and its influencing factors in the offices of sport and youth in Golestan Province. Through identifying the factors affecting the effectiveness and importance of each of them, athletic directors can design appropriate strategies in order to achieve the desired effectiveness and strive more than ever for the excellence of sports and athletics. Hence, the present study aims to deal with the relationship of corporate entrepreneurship and organizational culture with effectiveness in order to help the managers in achieving the desired effectiveness.

\section{MATERIALS AND METHODS}

This study is a correlation research.

Participants. Statistical population included all directors and experts of general directorates of sport and youth in Golestan province of Iran $(\mathrm{N}=280)$, and 164 persons were randomly selected as the sample.

Tools. The required data and information were collected by using three questionnaires. The questionnaires used in this study are as follows: 
1- Denison Organizational Culture Survey (DOCS) (14): This questionnaire measures the four components of organizational culture including involvement in work, integration, adaptability, and mission on a Likert's five-item scale $(1=$ totally disagree, $2=$ disagree, $3=$ neither agree nor disagree (abstention), $4=$ agree, $5=$ totally agree).

2- Corporate Entrepreneurship Inventory: This questionnaire is author-made and measures 6 parameters of corporate entrepreneurship including structure, goals realization, organizational culture, management support, reward system, and information system on a Likert's five-item scale $(1=$ very low, $2=$ Low, $3=$ somewhat, $4=$ high, $5=$ very high).

3- Effectiveness Questionnaire: Consisting of four dimensions including adaptation, goal achievement, integrity, and continuity \& reliability, this questionnaire has been used in several $\mathrm{PhD}$ theses and dissertations. The reliability and validity of this questionnaire has been already determined and accepted. Heydari Nejad and Saberi (2010) reported a reliability coefficient of 0.82 for Effectiveness Questionnaire (25).

To determine the content validity of the questionnaire, the views and comments of 10 professors of Sport Management, Public Management, and Entrepreneurship Management who were experts on statistics and research methods were taken. Confirmatory factor analysis method and Bartlett sphericity test were also used to determine the reliability of Corporate Entrepreneurship Inventory (Table 1).

The reliability of questionnaires of organizational culture, corporate entrepreneurship, and effectiveness was determined $0.86,0.94$, and 0.92 , respectively, by using Cronbach's alpha coefficient.

Statistical Analysis. The collected data were analyzed using Kolmogorov-Smirnov, Pearson correlation coefficient and multiple regression test to examine the hypothesis of the study. Significance levels accepted at $\mathrm{p}<$ 0.05 . All statistical analyses were performed using Statistical Package for Social Sciences software.

Table 1. Results of KMO test and confirmatory factor analysis of variables

\begin{tabular}{|c|c|c|c|}
\hline Variable & Index of KMO test & Index of Bartlett test & Eigenvalue \\
\hline Effectiveness in organization & 0.924 & 0.001 & 10.01 \\
\hline Corporate entrepreneurship & 0.913 & 0.001 & 10.09 \\
\hline Organizational culture & 0.813 & 0.001 & 7.536 \\
\hline
\end{tabular}

\section{RESULTS}

The participants' demographic information are descriptively are presented in Table 2 .

Descriptive indices of the studied variables in form of mean scores for the effectiveness, organizational culture and entrepreneurship are presented in Table 3.

Since the results of Kolmogorov-Smirnov test indicate that the distribution of data is normal, Pearson correlation coefficient test was used to assess the relationships. The results of this test showed that there is a significant and positive relationship between organizational culture and effectiveness $(\mathrm{r}=0.445)$. Among the subscales of organizational culture, involvement in work has the highest correlation $(r=0.422)$ with effectiveness, while adaptability is not significantly correlated with effectiveness (Table 4).

The results also showed that entrepreneurship has a positive and significant correlation with effectiveness $(r=0.795)$. Among the subscales of corporate entrepreneurship in offices of sport and youth in Golestan Province, culture and 
management support have the highest correlation with organizational effectiveness $(\mathrm{r}=0.730)($ Table 5).

Table 2. Demographic information of the participants

\begin{tabular}{cccc}
\hline Variables & Classification & Frequency & Percentage \\
\hline \multirow{2}{*}{ Gender } & Man & 91 & 55.5 \\
& Woman & 73 & 44.5 \\
\hline \multirow{4}{*}{ Age } & $20-24$ & 5 & 3 \\
& $25-29$ & 28 & 17.1 \\
& $30-35$ & 64 & 39 \\
& Other & 67 & 40.9 \\
\hline \multirow{2}{*}{ Marital Status } & Single & 33 & 20.1 \\
& Married & 131 & 79.9 \\
\hline \multirow{2}{*}{ Major } & Physical education & 59 & 36 \\
& Other majors & 105 & 64 \\
\hline \multirow{3}{*}{ Education level l } & Associate's degree & 48 & 29.3 \\
& Bachelor's degree & 89 & 54.3 \\
& Master's degree & 27 & 16.4 \\
\hline \multirow{3}{*}{ Organizational post } & Director & 8 & 4.9 \\
& Assistant director & 7 & 4.3 \\
& Expert & 149 & 90.9 \\
\hline \multicolumn{2}{c}{ Total } & 164 & 100 \\
\hline
\end{tabular}

Table 3. Mean scores for the effectiveness, organizational culture and entrepreneurship

\begin{tabular}{ccccc}
\hline Variables & Mean & Standard deviation & Minimum & Maximum \\
\hline Effectiveness & 3.56 & 0.60 & 1.71 & 4.77 \\
\hline Organizational culture & 3.17 & 0.47 & 2.19 & 4.41 \\
\hline Corporate entrepreneurship & 3.48 & 0.68 & 1.67 & 4.77 \\
\hline
\end{tabular}

Table 4. The relationship of organizational culture and its subscales with effectiveness

\begin{tabular}{lcc}
\hline Organizational Culture and its subscales & Correlation coefficient with Effectiveness & $\mathrm{p}$ \\
\hline Organizational culture & 0.445 & $0.001^{* *}$ \\
\hline Involvement in work & 0.422 & $0.001^{* *}$ \\
\hline Integrity & 0.340 & $0.001^{* *}$ \\
\hline Adaptability & 0.122 & 0.12 \\
\hline Mission & 0.398 & $0.001^{* *}$ \\
\hline \multicolumn{2}{r}{ * Significance level $\mathrm{p}<0.01$}
\end{tabular}

Table 5. The relationship of corporate entrepreneurship and its subscales with organizational effectiveness

\begin{tabular}{lcc} 
Corporate Entrepreneurship and its subscales & Correlation coefficient with Effectiveness & $\mathrm{p}$ \\
\hline Corporate Entrepreneurship & 0.795 & $0.001^{* *}$ \\
\hline Structure & 0.590 & $0.001^{* *}$ \\
\hline Goals realization & 0.579 & $0.001^{* *}$ \\
\hline Organizational culture & 0.730 & $0.001^{* *}$ \\
\hline Management support & 0.730 & $0.001^{* *}$ \\
\hline Reward system & 0.603 & $0.001^{* *}$ \\
\hline Information system & 0.510 & $0.001^{* *}$ \\
\hline
\end{tabular}

**Significance level $\mathrm{p}<0.01$ 
The results suggest that there is significant positive relationship between corporate entrepreneurship and organizational culture $(\mathrm{r}=0.410)$. Among the subscales of corporate entrepreneurship, culture and reward system have the highest correlation with organizational culture (Table 6).
Multiple regression test show corporate entrepreneurship and organizational culture are predictors of effectiveness in offices of sport and youth in Golestan Province of Iran. The regression equation was obtained using the stepwise method (Table 7 and Table 8).

\begin{tabular}{lcc} 
Table 6. The relationship of corporate entrepreneurship and its subscales with organizational culture \\
\hline Corporate Entrepreneurship and its subscales & Correlation coefficient with Effectiveness & $\mathrm{p}$ \\
\hline Corporate Entrepreneurship & 0.410 & $0.001^{* *}$ \\
\hline Structure & 0.271 & $0.001^{* *}$ \\
\hline Goals realization & 0.257 & $0.001^{* *}$ \\
\hline Organizational culture & 0.376 & $0.001^{* *}$ \\
\hline Management support & 0.364 & $0.001^{* *}$ \\
\hline Reward system & 0.380 & $0.001^{* *}$ \\
\hline Information system & 0.359 & $0.001^{* *}$ \\
\hline & $* *$ Significance level p $<0.01$ &
\end{tabular}

Table 7. Prediction of effectiveness by corporate entrepreneurship and organizational culture

\begin{tabular}{ccccc}
\hline Variables entered into the model & $\mathrm{R}$ & $\mathrm{R}^{2}$ & $\mathrm{~F}$ & $\mathrm{p}$ \\
\hline Corporate entrepreneurship & $0.795^{\mathrm{a}}$ & 0.632 & 278.735 & $0.001^{* *}$ \\
\hline Organizational culture & $0.806^{\mathrm{b}}$ & 0.649 & 149.074 & $0.001^{* *}$ \\
\hline \multicolumn{2}{c}{$*$ Significance level $\mathrm{p}<0.01$} &
\end{tabular}

Table 8. Coefficients of prediction of effectiveness by corporate entrepreneurship and organizational culture

\begin{tabular}{ccccc}
\hline Steps of regression & Variables entered into the model & Intercept & Slope of the regression line & $\mathrm{p}$ \\
\hline First & Corporate Entrepreneurship & 1.118 & 0.704 & $0.049^{*}$ \\
\hline \multirow{2}{*}{ Second } & \multirow{2}{*}{ Organizational Culture } & \multirow{2}{*}{0.718} & 0.653 & $0.048^{*}$ \\
\cline { 4 - 5 } & & & 0.183 & $0.01^{*}$ \\
\hline
\end{tabular}

*Significance level $\mathrm{p}<0.05$

According to table 7 and 8 , regression equation for prediction of effectiveness is as follows:

Organizational Effectiveness $=0.718+$ $(0.653 \times$ Corporate Entrepreneurship $)+$ $(0.183 \times$ Organizational Culture $)$

\section{DISCUSSION AND CONCLUSION}

The findings revealed the relationship of organizational culture and its subscales with effectiveness in offices of sport and youth of Golestan Province. This result is consistent with the findings of Sheykhalizadeh and Tojjari (2012), Gregory et al. (2009), Kwantes and Boglarsky (2007), Faerman (2009), Denison et al. (2006), Denison, Haaland, and Goelzer (2004), Coffey (2003), Ghorbani, Asadi, and Sharifi (2010), Yilmaz and Ergun (2008), Fey and Denison (2003), and Hsu (2002). These studies showed that organizational culture can increase the ability of employees to gain internal satisfaction and thereby job satisfaction, and generally there is a significant relationship between organizational culture and effectiveness (4, 6, 14, 19-22, 26-29). It should 
be also noted that if organizational culture, that embraces the core values of an organization, has a broad audience and is accepted by the most members of an organization, it puts the employees of that organization together and they try to reach the main destination of the organization. Teamwork, leaving a dry and bureaucratic system, support for risk takers, delegation of authorities, control coupled with freedom of action, and appreciation of ethics, integrity, and sacrifices all are effective in promoting organizational culture in offices of sport and youth and cause all members of an organization move seamlessly to achieve organizational goals.

The findings of the present study indicate that corporate entrepreneurship and its subscales has a relationship with effectiveness in offices of sport and youth of Golestan Province. This is consistent with the results of obtained by Seifisaldehi et al. (2012) and Karimpour, Imani, and Chehrzad (2012) who concluded that components of corporate entrepreneurship (structure, goals realization, organizational culture, management support, reward system, and information system) in an entrepreneurial organization can play a great role in correct decision-making and doing the right things, which is called effectiveness (23, 24). Corporate entrepreneurship, which involves two dimensions of innovation and strategy renewal according to Zahra (1991) (30) and includes three components of self-efficacy, innovation, and risk-taking as Miller (1983) (31) mentions, can be realized when there is a flexible and effective structure accompanied by a collaborative management and enthusiasm for debate, discussion, and numerous meetings in a teamwork in an organization. Such a structure has a positive and direct relationship with effectiveness which is the extent to which an organization achieve short-term and long-term goals according to the expectations of beneficiaries and investigators, as Robbins (1974) (32) argues (33).

Specifically, in an organization where the staff, beyond their organizational position and rank, can express their opinions, show their innovations, and take risks; organizational culture encourages change and innovation, organizational learning, future-orientation, teamwork, honesty, and trust; the management support and reward the entrepreneurs and innovators; and everyone can easily access the relevant information, employees can assist the organization to achieve its goals. In this regard, creativity and innovation of employees can relief shortage of equipment and financial, human, and other obstacles. Traditionally it has been always stressed that the lack of financial resources and facilities is the reason of failure, but facilities and financial resources are not the only determinants in today's world and Innovation, multifunctional use of resources, and economic savings can be helpful in order to achieve the objectives. It should always be remembered that entrepreneurship can be flourished within the privations. According to the characteristics of sport which forms the basis of sport organizations and is always associated with innovation, the traditional and rigid bureaucratic structure of sport and youth offices can be made more flexible. For this purpose, authorities should be delegated to employees and self-efficacy and risk-taking should be encouraged.

The results also showed that there is a relationship between corporate entrepreneurship and organizational culture in offices of sport and youth in Golestan Province. This is consistent with the findings of Nayager and Van Vuuren (2005), Echols and Neck (1998), Seyedhoseini (2002), Mirzaei Ahranjani and Moghimi (2003), Smerek and Denison (2007), Denison et al. (2006), and Kuratko and Hodgetts (1992) who stated that creation and reinforcement of an entrepreneurial culture has a direct relationship with organizational and managerial parameters. Creation of such cultures is aiming to increase the innovation capabilities of employees which can lead to increased organizational success by creating new organizational innovations (11, $14-18,34)$. Findings of this study also show that 
there is a direct and significant relationship between components of corporate entrepreneurship (structure, realization of goals and entrepreneurial culture, organizational culture, management support, reward system, and information system). In other words, promotion of the cultural context of organizations through its components encourages entrepreneurship and consequently leads to organizational effectiveness and efficiency.

In addition, these studies emphasize the fact that organizational culture can stimulate and accelerate the process of corporate entrepreneurship if it supports targeted risk and variability, innovation, and new ideas at all organizational levels; strengthens the trust between employees and management, assumes the staff a valuable resources for organization, values all things the staff do, and controls them with freedom of action. The results of the present study suggest that corporate entrepreneurship and organizational culture are significant predictors for effectiveness. The results of other studies about the relationship of corporate entrepreneurship and organizational culture with effectiveness all have a consensus upon the relationship and expression of prediction through multiple regression. So, the findings of the present study are consistent with the results of previous studies. Corporate entrepreneurship, through strengthening its own components, can help the members of an organization to achieve the organizational objectives (effectiveness).
Regarding the relationship of organizational culture and corporate entrepreneurship with effectiveness, the following suggestions are offered:

- It is recommended that the directors of offices of sport and youth in Golestan Province embark on the establishment of an entrepreneurial structure in their organizations. Such a structure could provide development and growth of employees and increase the effectiveness of their activities.

- It is recommended that the emphasis on careful and indisputable observation and compliance with organizational hierarchy is reduced and team-building to be used as one of the factors of entrepreneurial culture in offices of sport and youth in Golestan Province.

- It is recommended that laws and regulations to be developed in organizations to encourage risk-taking, creativity, and innovation among the employees.

- It is recommended that senior managers delegate more authority junior directors and provide them with required resources and facilities to take decisions in their areas of expertise with more freedom of action.

It is recommended that duties and achievement of organizational objectives are emphasized rather than mere compliance with laws and regulations. Also, it is better to avoid to develop various and different laws and regulations on specific topics.

\section{REFFRENCES}

1. Ahmadi M. Fundamentals of Organization and Management. 6th ed: Shahr Press Publication; 2007 [Book in Farsi].

2. Chelladurai P, Haggerty TR. Measures of organizational effectiveness of Canadian national sport organizations. Canadian journal of sport sciences $=$ Journal canadien des sciences du sport. 1991;16(2):126-33.

3. Ghafouri F, Ashraf Ganjouei F, Dehghan A, Hoseini M. The Relationship between Managers' Leadership Style and Creativity of Physical Education Teachers. Journal of Sport Management. 2009;1(2):215-448 [Article in Farsi].

4. Kwantes CT, Boglarsky CA. Perceptions of organizational culture, leadership effectiveness and personal effectiveness across six countries. Journal of International Management. 2007;13(2):204-30.

5. Zhang M, Li H, Wei J. Examining the relationship between organizational culture and performance: The perspectives of consistency and balance. Front Bus Res China. 2008;2(2):256-76.

6. Sheykhalizadeh M, Haris., Tojjari F. The effect of transformational leadership and Organizational Culture with Organizational Effectiveness in Sport Organizations. Sport Management Review. 2012(17):45-56 [Article in Farsi]. 
7. Haghshenas A, Jamshidian M, Shaemi A, Shahin A, Yazdanshenas M. An Organizational Entrepreneurship Framework for Iran's Public Sector. Iranian Journal of Management Studies. 2008;2(8):31-73 [Article in Farsi].

8. Hadizadeh A, Moghadam., Raminmehr H, Hosseini SS. Relationship between Emotional Intelligence and Entrepreneurial Orientation among the Employees of Oil Company-Affiliated Organizations. Journal of Entrepreneurship Development. 2009;1(4):139-62 [Article in Farsi].

9. Landstrom H. Pioneers in entrepreneurship and small business research: Springer Science \& Business Media; 2007. 381 p.

10. Guzmán Cuevas J, Cáceres Carrasco F. Entrepreneurial Structure Qualitative Analysis: The Case of Seville (Spain). Int Adv Econ Res. 2007;13(4):488-94.

11. Nayager T, Van Vuuren JJ. An analysis of an organisational strategy, structure and culture that supports corporate entrepreneurship in established organizations. SAJEMS. 2005(1):29-38.

12. Marlow S. Human resource management in smaller firms: A contradiction in terms? Human Resource Management Review. 2006;16(4):467-77.

13. Pertusa-Ortega EM, Zaragoza-Sáez P, Claver-Cortés E. Can formalization, complexity, and centralization influence knowledge performance? Journal of Business Research. 2010;63(3):310-20.

14. Denison DR, Janovics J, Young J, Cho HJ. Diagnosing organizational cultures: Validating a model and method. Documento de trabajo. Denison Consulting Group, 2006.

15. Mirzaei H, Ahranjani, Moghimi SM. Journal of Management Knowledge. 2003;16(2):101-38 [Article in Farsi].

16. Smerek RE, Denison DR, editors. Social Capital in Organizations: Understanding the Link to Firm Performance. Sixty-Sixth Annual Meeting of the Academy of Management; 2007: Academy of Management.

17. Kuratko DF, Hodgetts RM. Entrepreneurship : a contemporary approach. Fort Worth [etc.]: Dryden; 1992.

18. Seyedhoseini M. Identification of priority indicators for achieving entrepreneurial organizations in the country: University of Science and Technology; 2002 [Thesis in Farsi].

19. Faerman LB. The relationship between organizational culture and effectiveness in university residence hall associations: A competing values study. Boca Raton, Florida: Florida Atlantic University; 2009.

20. Ghorbani MH, Asadi H, Sharifi M. The Relationship between Organization Culture and Effectiveness in Physical Education Organization of Islamic Republic of Iran based on Denison's Model. Journal Of Movement Science \& Sports. 2010;7(14):107-18 [Article in Farsi].

21. Gregory BT, Harris SG, Armenakis AA, Shook CL. Organizational culture and effectiveness: A study of values, attitudes, and organizational outcomes. Journal of Business Research. 2009;62(7):673-9.

22. Yilmaz C, Ergun E. Organizational culture and firm effectiveness: An examination of relative effects of culture traits and the balanced culture hypothesis in an emerging economy. Journal of World Business. 2008;43(3):290-306.

23. Seifisaldehi MH, Kozehchian H, Ehsani M, Seifisaldehi M. The Effect of Entrepreneurial Structure on Organizational Effectiveness in Physical Education Organization of Islamic Republic of Iran. Sport Management Review. 2012;4(13):215-36 [Article in Farsi].

24. Karimpour A, Imani J, Chehrzad I, editors. Examine the relationship between organizational effectiveness and entrepreneurial point of view of an industrial organization in the city of Bandar Abbas. National Conference of Entrepreneurs (Knowledge-based Industry); 2012 [Article in Farsi].

25. Heydari Nejad S, Saberi A. The Relationship Between styles of leadership and Effectiveness of Directors P.E Administrations in Lorestan province. Bulletin of Sport Management \& Motor Behavior. 2010;6(11):75-87 [Article in Farsi].

26. Coffey $\mathrm{V}$. The organizational culture and effectiveness of companies involved in public sector housing construction in Hong Kong. 23rd International Conference of CIB TG; Hong Kong2003.

27. Denison DR, Haaland S, Goelzer P. Corporate Culture and Organizational Effectiveness: Is Asia Different From the Rest of the World? Organizational Dynamics. 2004;33(1):98-109.

28. Fey CF, Denison DR. Organizational culture and effectiveness: can American theory be applied in Russia? Organization Science. 2003;14(6):686-706.

29. Hsu C-H. A Structural Equation Modeling Analysis of Transformational Leadership, Organizational Culture and. Organizational Effectiveness in Taiwanese Sport/Fitness Organizations 2002.

30. Zahra SA. Predictors and financial outcomes of corporate entrepreneurship: An exploratory study. Journal of Business Venturing. 1991;6(4):259-85.

31. Miller D. The Correlates of Entrepreneurship in Three Types of Firms. Management Science. 1983;29(7):770-91.

32. Robbins SP. Managing organizational conflict: a nontraditional approach: Prentice-Hall; 1974.

33. Kalateh M, Seifari, Tondnevis F. The Relationship between Organizational Culture and Organizational Entrepreneurship in Physical Education Headquarter of Tehran. Research in Sport Management and Motor Behavior. 2013;2(4):105-17 [Article in Farsi].

34. Echols AE, Neck CP. The impact of behaviors and structure on corporate entrepreneurial success. Journal of Managerial Psychology. 1998;13(1/2):38-46.

Kalateh, M. Seifari., Amoozadeh, Z. (2014). Ann Appl Sport Sci, 2(3): 51-60. 


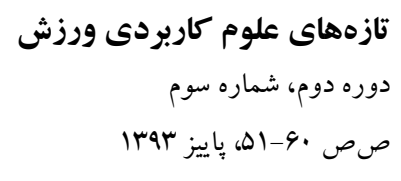

مقاله اصيل

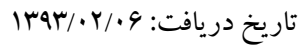

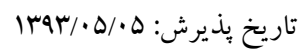

\section{رابطه بين فرهنَ سازمانى و كار آفرينى سازمانى با اثربخثى در سازمان هاى ورزشى}

\section{'معصومه كلاته سيفرى*، 'ّزهرا عموزاده}

- استاديار كروه مديريت ورزشى، دانشكده تربيتبدنى و علوم ورزشى، دانشكاه مازندان، بابلسر، ايران.

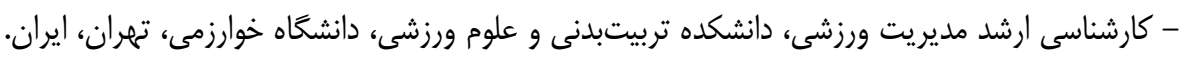

جكيده

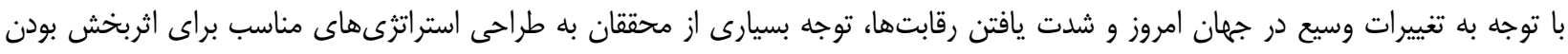

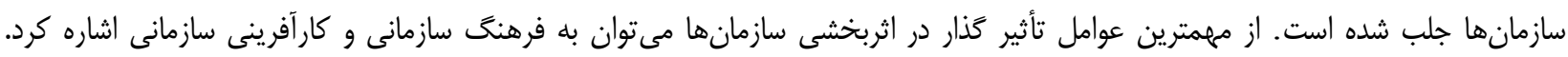

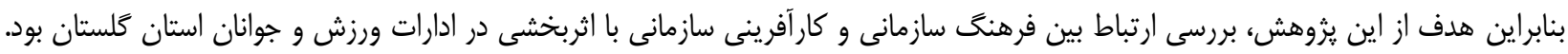

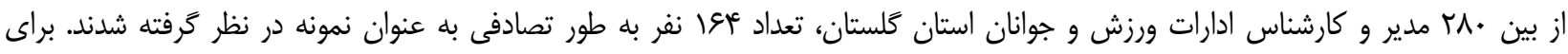

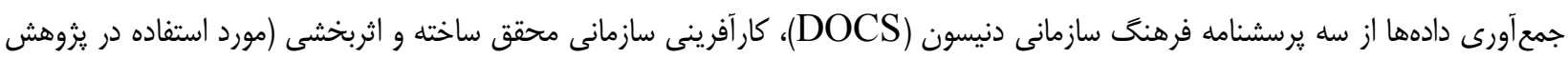

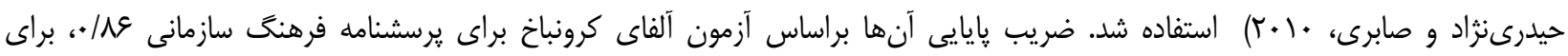

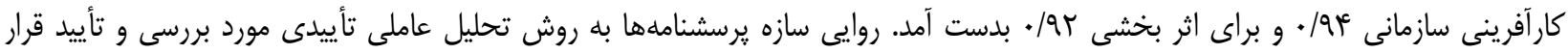

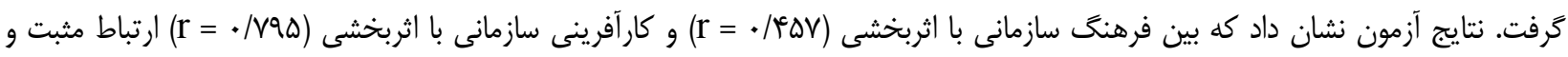

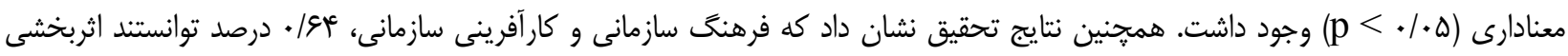

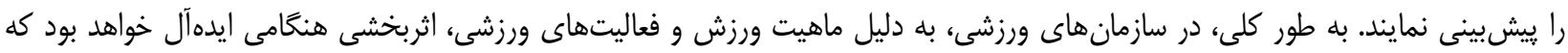

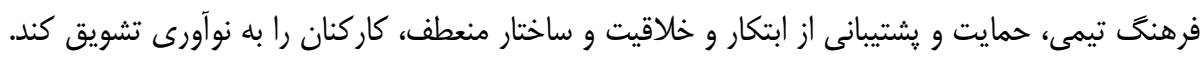

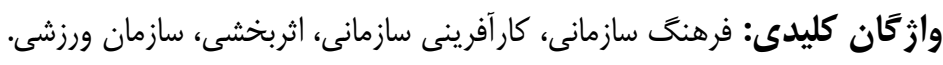

